\title{
Japanese Industrial Policy: The Case of Iron and Steel Industry
}

\section{Dr. Edita Đapo}

International University of Sarajevo

\begin{abstract}
The purpose of this paper is twofold. The first purpose is to contribute in understanding the rationale for intervention in iron and steel industry in Japan after World War II. The infant industry argument is explained and all criteria for protection discussed. The second purpose is to analyze and evaluate protection policy in the Japanese iron and steel industry in the period from 1950 to 1970. In order to evaluate protection policy a partial equilibrium approach is used to calculate the country's welfare effects from trade barriers. The results show that the domestic consumers had suffered the loss for first ten years, but in the next ten years they gained more than four times from protection.
\end{abstract}

Keywords: Industrial Policy, Protection, Infant Industry Argument, Welfare Effects, Consumers' Costs and Benefits. 


\section{INTRODUCTION}

In the literature of development economics a lot of attention was paid to the growth of Japan after World War II. Considering that Japan had lost all its empire and

25 percent of its wealth, the achievement in the rapid development was noticed and had to be explained. The existence of a favorable external environment such as the growth of world trade, the availability of foreign technologies, the Korean War and the payments by the USA for Japanese defense, may have played a great role in Japanese economic development, but researches on this subject "agreed that Japan's rapid economic growth was not made possible by macroeconomic policy alone" (Sazanami 1994, pp.116). Economists were and still are interested in the model of Japanese development in order to draw lessons which might be useful in the economic development of other countries.

There are a wide range of different views regarding the efficacy of Japanese industrial policy in promoting the competitiveness of specific industries. There are different kinds of approaches evaluating the industrial policy of Japan. Many studies on this subject utilize an institutional approach (Itoh 1994, Komiya 1990, Krenin 1991, Sakurai 2000). They explain what kinds of institutions are needed for effective formulation of the industrial policy and what results are achieved. A second approach, which will be used in this paper, focuses on the evaluation of the industrial policy in the specific industry. I will take the iron and steel industry as an example.

H. Muller and K. Kawahito (1978) compared amounts and types of investments in major iron and steel producers countries and find out that Japanese iron and steel industry was able to make large gains in productivity because of the protection. However, Japanese steel industry did not gain comparative advantage merely by enlarging the size of factory unit. Technological innovation helped Japanese iron and steel industries to achieve economies of scale and cost competitiveness (Yonekura 1991, Odagiri at. al 1996). Krugman (1987) criticized that Japanese industrial policy applied to the iron and steel industry after the war was not efficient. However, Komiya (1990) compared Krugman's data with Crandall's data (1981) of the USA and found out that the iron and steel industry in Japan has 
achieved better results than the iron and steel industry in the USA.

It is still needed to explain if the protection of iron and steel industry in post- war Japan was justified. The purpose of this paper is to do that. The aim of this paper is twofold. The first is to contribute in understanding the rationale for protection of the iron and steel industry. The second is to analyze and evaluate protection policy in this industry in the period from 1950 to 1970.

The paper is organized as follows: next section consists of the explanation of the infant industry argument. The third section gives the evaluation of the protection policies in the sense of national economic welfare. The last section presents the conclusion.

\section{THE INFANT INDUSTRY ARGUMENT}

The infant industry argument is the oldest and the best known rationale for intervention of an industry. It has offered not just justification for industrial policy but make strong case for necessity of government intervention while the industry is in the infancy stage. The analysis of this argument can be based on two versions: economies of scale (static concept) and economies of time (dynamic concept). The first version claims that young industries will achieve economies of scale when protection gives them preferential access to the domestic market. Economies of scale result in falling costs as the scale of output at any point in time increases. The second version claims that young industries will achieve economies of experience when protection gives them a time for learning by doing. Economies of time result in falling costs as the length of time.

As Japan made its postwar industrialization process under the protection and this argument provides basic framework for analyzing Japanese industrial policy applied in iron and steel industry in the 1950s. Vestal (1993) was first who noticed the need for defining if the iron and steel industry was an infant industry. This question is crucial because if it was not an infant industry than it did not required government support. Every textbook of the industrial organization explains that industry goes through three phases: infancy, maturity and declination over the time. An infant industry, by definition, is an industry that currently cannot survive in free trade conditions without protection, but will acquire a competitive edge against 
foreign competitors by accumulating production experience and/or employing economies of scale if it is temporarily protected during the initial stage of development.

If we consider duration of the industry's existence, than the Japanese iron and steel industry was not in the infancy stage, because the industry has been operating since Meiji Era. In addition, in pre-war period Japanese iron and steel industry "accumulated both technological and organizational skills at quite high level when compared with world standards" (Yonekura 1991, pp.203). Odagiri and Goto (1996) were eager to outline that production technology in the iron and steel industry was at high level before the War. This means the industry had accumulated experience and knowledge during its existence.

Table 1. Crude steel's production in major countries (in thousand tons)

\begin{tabular}{|l|l|l|l|l|}
\hline Year & USA & Japan & UK & Germany \\
\hline 1875 & 369 & 1 & 719 & 371 \\
\hline 1900 & 10,352 & 1 & 4,980 & 6,646 \\
\hline 1940 & 60,766 & 6,856 & 13,184 & 19,141 \\
\hline 1946 & 60,421 & 557 & 12,899 & 2,551 \\
\hline 1950 & 87,848 & 4,839 & 16,554 & 12,121 \\
\hline 1955 & 106,173 & 9,408 & 20,008 & 21,335 \\
\hline 1960 & 90,067 & 22,138 & 24,995 & 34,100 \\
\hline 1965 & 119,260 & 41,161 & 27,439 & 36,821 \\
\hline 1969 & 127,976 & 82,166 & 26,855 & 45,316 \\
\hline
\end{tabular}

Source: Ministry of Trade and Industry, Yearbook of Iron and Steel Statistics

However, to answer the question if the iron and steel industry was in infancy stage we have to analyze its competitiveness immediately after the War. At that time, production in Japanese iron and steel industry was almost nonexistent and because it has to start its production from zero it is considered as an infant industry. Furthermore, the costs of production were too high that it would not survive under the free trade. In the Table 1 it is shown that volume of the production was at a very law level comparing to its international rivals. 


\section{CRITERIA FOR PROTECTIONISM}

Neoclassical theory holds that the protection of an infant industry can be justified only under somewhat stringent conditions (Kemp 1960). There are four tests which should be satisfied if the industry deserves to be protected. As I am analysing the development of the iron and steel industry that occurred in the period from 1950 to 1970, I can make analysis if and when those tests were satisfied.

Mill's Test - For the protection to be really temporary it is necessary that the industry in question should in fact eventually become selfsustaining. This requires the productivity to increase over the time such that the industry can eventually be able to compete under the free trade.

Table 2. Labor Productivity in Major Producers Country (Yearly crude steel production in tones divided by number of workers)

\begin{tabular}{|l|l|l|l|l|}
\hline Year & USA & Japan & UK & Germany \\
\hline 1959 & - & 78.9 & 83.1 & 90.4 \\
\hline 1962 & 187.6 & 105.8 & 89.8 & 96.2 \\
\hline 1965 & 221.5 & 159.6 & 113.1 & 118.4 \\
\hline 1969 & 247.6 & 301.1 & 125.6 & 156.3 \\
\hline
\end{tabular}

Source: Ministry for Trade and Industry, Yearbook of Iron and Steel Statistics

In Table 2 it is shown that Japanese iron and steel industry took the first position in the world regarding the labor productivity. Corden (1974) states that the Mill's test is satisfied when the average costs are equal the import price. Most textbooks of the international trade and economic development indicate this to be the timing for the protection removal. As the data on import prices are non-existent, I will base my discussion on the comparison of the average costs and the world prices. This comparison is presented in Table 3. In 1956 the world price of finished steel and

Japanese average costs are almost equal and this is the year when Mill's test is satisfied. It can be seen that Japanese iron and steel companies reached cost competitiveness in 1958. 
Table 3. World Price, Average Cost of Production and Domestic Price of Finished Steel in Japan and USA (in \$US)

\begin{tabular}{|l|l|l|l|l|l|}
\hline Year & \multicolumn{1}{|l|}{$\begin{array}{c}\text { World } \\
\text { Price }\end{array}$} & $\begin{array}{c}\text { Average } \\
\text { Production } \\
\text { Costs Japan }\end{array}$ & $\begin{array}{c}\text { Average } \\
\text { Production } \\
\text { Costs USA }\end{array}$ & $\begin{array}{c}\text { Domestic } \\
\text { Price } \\
\text { Japan }\end{array}$ & $\begin{array}{c}\text { Domestic } \\
\text { Price USA }\end{array}$ \\
\hline 1956 & 130.0 & 131.7 & 100.6 & 175 & 119 \\
\hline 1958 & 126.2 & 89.5 & 110.8 & 148 & 127 \\
\hline 1960 & 134.0 & 77.2 & 109.0 & 125 & 147 \\
\hline 1965 & 141.6 & 69.3 & 102.5 & 123 & 161 \\
\hline 1968 & 153.4 & 61.5 & 108.3 & 116 & 199 \\
\hline
\end{tabular}

Source: Japanese Association of Iron and Steel, World of Iron and Steel

Bastable Test - social benefits from the industry when it is mature should more than compensate for the social costs incurred in protecting the industry in its infancy. This means that price should decrease over the time. The period when the protection should be removed is the time when the average costs are less than the imported price or world average price. From the data in Table 3 it can be said that Bastable test was satisfied in 1958.

Kemp Test - is based on the presence of the uncertainty and the imperfection of the capital market. The capital market's imperfection was solved through the establishment of the Japan Development Bank, which supported the iron and steel industry with the low interest loans. Uncertainty is connected to the technological improvements. If firms within an industry can collect the benefits of the learning process, there is no need to protect them socially, since they can make up for their initial private losses by their future private profits. However, if the outcome of the learning process cannot be accumulated this constitutes legitimate reasons for protecting infant industries. Until 1958, private agents adopted various types of the

Inquipy $2015 / 2$ new technologies of which main are the blast oxygen furnace and continuous casting process technologies. This justifies protection in Japanese iron and steel industry.

Neigishi Test - there is a clear case for protecting the infant industry if the country is 'large enough' in jargon of international trade theory. Suppose that the expansion of output by a present day infant industry reduces the international relative price of its product in the future. Decrease of international price in future will increase consumer surplus and this is the case where protecting today's 
infant industry may yield higher overall level of world's economic welfare. The Table 3 shows that the Japanese iron and steel prices had an influence on the world price since 1960s. As it can be seen that all tests were satisfied until 1960, this is the year when protection could be removed.

It is difficult for an industry to become established without temporary protection by the government. In general, which industry should be promoted depends not only on the industry itself but also on the industrial structure of the country, as well as on the structure of demand in the world as a whole. Policies to protect and promote an infant industry can be justified for the developing country, but it has to be evaluated how those policies have affected countries economic welfare.

\section{PARTIAL EQUILIBRIUM APPROACH}

Protective measures may be estimated in the general or partial equilibrium. For my estimation, I will concentrate on the partial equilibrium model. If the good is homogenous, has the same price in the import and domestic markets, all changes could be present in one figure and application of the Corden-Johnson modell would be possible. This model is applicable only in analysis where the domestic price is enlarged just for the tariff. However, application of CordenJohnson methodology to evaluate protection in Japan would be inappropriate because the Japanese market was not only protected by formal tariffs but by the import quotas and other measures as well. That is why I have to separate domestic and import markets and apply a model that was designed by Hofbauer and Elliott (1994). 


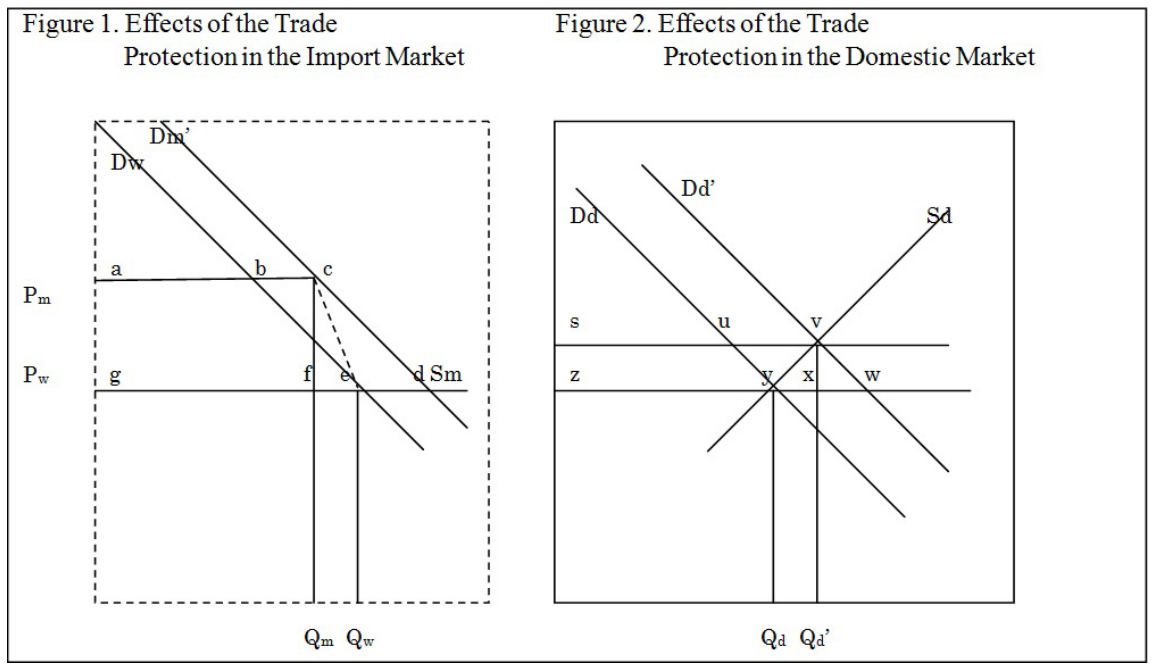

The framework is founded on the partial equilibrium analysis with three key assumptions: (a) the domestic good and the imported good are perfect substitutes, (b) the supply schedule for the imported good is flat (perfectly elastic) which shows that country is small, and as the iron and steel was an infant industry, it was small comparing to other foreign rivals, and (c) the supply schedule for the domestic good is upwardly sloped (less than perfectly elastic).

The effects of the barriers (either a tariff or a quota) under these assumptions are illustrated in Figure 1. and Figure 2. Trade policy raises the import price of steel by tariff $(\mathrm{Pm}-\mathrm{Pw})$ or lowers import by $(\mathrm{Qw}-\mathrm{Qm})$ in the case of the quantity restrains. The increase of the import price shifts the domestic demand curve from Dd to Dd'. The increase in import price leads domestic suppliers to raise price by the Pd, which in turns raises the import demand schedule to Dm. The post restriction equilibrium is given by Pm, Qm, Pd' and Qd'.

\section{EFFECTS}

In a short-run, the changes in prices and quantities due to trade protection results in a loss of consumer surplus, both in import market and in the domestic market. However, in a case of the protection which is imposed in order to develop an industry, today's protection might results in gain of consumer surplus in the future. The trade restrictions will provide producer's gain and consumer's surplus. If the trade restrain take a form of tariff, than the government tariff revenue will arise. If non-tariff barriers such as an import quota 
are imposed, the rent to the domestic importers ${ }^{1}$ will be created. Finally, there would be an efficiency loss because the trade restrain effected the allocation of the resources.

The methodology used here to quantify these welfare effects in based on assumption that goods are perfect substitute. The consumer's surplus loss from trade barriers in the import market is approximated by the area bounded by points aceg in Figure 1. This method of estimating the consumer loss in the imported market gives an average of the consumer loss calculated separately from the two demand curves. Jones (1993) gave a mathematical proof of the validity of this method. Using the new demand schedule (Dm) gives the area marked acdg as the change in the consumer surplus, while the old demand schedule (Dw) gives the area marked abeg. The difference between the two areas is shown by the parallelogram marked bcde. Line ce divides the area in half and gives the compromise consumer surplus change, area aceg. Area aceg can be estimated by adding rectangle acfg to triangle cef.

If the form of protection is tariff, the rectangular area acfg represent the government tariff revenues, and may be estimated as: $(\mathrm{Pm}-\mathrm{Pw}) \times \mathrm{Qm}$. The area of the triangle marked cef represent loss, which may be estimated as: $\left.1 / 2 \times\left[(\mathrm{Pm}-\mathrm{Pm})^{\prime}\right) \times\left(\mathrm{Qm}^{\prime}-\mathrm{Qm}\right)\right]$.

The effects in the market for the domestically produced good (Figure 2) are as follows: the consumer welfare loss from higher domestic prices may be approximated by the area marker svyz. Area swyz can be estimated by subtracting rectangle svxz and triangle vxy. This amounts to: $\left(\mathrm{Pd}^{\prime}-\mathrm{Pd}\right) \times \mathrm{Qd}^{\prime}-1 / 2 \times\left[\left(\mathrm{Pd}^{\prime}-\mathrm{Pd}\right) \times\left(\mathrm{Qd}^{\prime}-\mathrm{Qd}\right)\right]$.

In the domestic market, the consumer loss is just offset by the producer's surplus gain.

\section{THE WELFARE EFFECTS IN THE JAPANESE IRON AND STEEL INDUSTRY}

Because Japanese iron and steel industry become the world's biggest steel exporter, we may conclude that protection at the early period was justified. Krugman (1991) has explained how the protection can work as force for export promotion. Anyhow, in order to check difference between the loss and gain in the domestic market, it is needed to compare how much the domestic consumers actually have

\footnotetext{
${ }^{1}$ In Japan domestic importers generally capture the quota rents that arise from non-tariff barriers
} 
paid for finished steel products in the protected domestic market, as well as how much they would pay if there were no protection. In that sense, I will compare real expenditures consumer paid at the domestic market with the "hypothetical" expenditures they would pay in the absence of the trade barriers. During the period from 1950 to 1970, the domestic consumers paid US\$47,041,986,000on domestic market and US\$372,929,360 on import market. Domestic consumers' total expenditures for the finished steel products are US\$47,141,915,360.

Assume that domestic consumers were consuming the same quantity $(\mathrm{Qc}=\mathrm{Qd}+\mathrm{Qm})$ and paying world's prices $(\mathrm{Q} c \times \mathrm{Pw})$ total expenditures would be US $\$ 53,394,843,800$. In this calculation I used average world price that include the price of the Japanese producers which in the late 1950s become the cheapest price in the world's market. The difference between the real expenditure and expenditures that would occur in the absence of the trade barriers is US\$ $6,252,928,440$. This means that the domestic consumers at the beginning of protection process were facing a loss but in the future they gained from the development of the infant industry. In the period of twenty years, Japanese consumers benefited more than US\$ 6 billion. If we assume that the iron and steel industry in Japan was not established and exclude the Japanese domestic price in the process of calculating the average world price, the consumer gain would be even more. For their consumption they would pay US $\$ 55,033,840,000$, and the difference between the real expenditure and the calculated one would be US\$ 7,891,924,640.

The consumer surplus gain at the domestic market in the twenty years is US\$ 5,988,004,800 (difference between gain and loss). In first ten years, the domestic consumers suffered a loss, but in the last ten years their gain was four times larger. On the import market, if we ignore the efficacy loss, the consumer loss is equal to the government tariff revenue which is equal to almost US\$ 49 million.

To find the efficacy losses in the import and domestic markets it is common practice to compare the volume of imported goods before or after the restriction. In the case of the postwar iron and steel industry in Japan it is no use comparing the data with prewar period, as much as, comparing it with period after 1970 when the industry was already in the mature phase. In the absence of the data of elasticities or the data of the produced and imported volume changes 
that would happened in the absence of the trade barriers we cannot find the real efficacy losses.

\section{CONCLUSION}

It is difficult for an industry to become established without temporary protection by the government. Theoretically, the protection of the infant industry can be justified if there is possibility for static or dynamic externalities to occur. There are four tests to be considered when protecting an industry. In a case of Japanese iron and steel industry all four test for protection were satisfied.

Policies to protect and promote an infant industry can be justified for the developing country, but it has to be evaluated how those policies have affected countries economic welfare. In the case of the Japanese iron and steel industry, the improvement in production process was achieved so that prices of the product were declining compared to other foreign rivals. Thus, in the long run not just domestic but foreign users of these products gained. The iron and steel domestic consumer had suffered the loss for the first ten years, but in the next ten years they gained more than four times. This is the reason why the iron and steel industry deserved to be protected in the process of the development of Japan.

\section{REFERENCES}

Corden W.M. (1974) Trade Policy and Economic Welfare, Oxford, Clarendon Press

Crandall R.W. (1981) The U.S. Steel Industry in Recurent Crisis: Policy Options in a Competitive World, Brooking Institute, Washington D.C.

Hufbauer, G.C and K.A. Elliott (1994) Measuring the Costs of Protection in the United States, Institute for International Economics, Washington D.C.

Itoh T. (1994) The Japanese Economy, The MIT Press, Cambridge

Jones M. (1993) "The Geometry of the Protectionism in the Imperfect Substitute Models: A Reminder", Southern Economic Journal, Vol. 60, p.235-38

Kawasaki T. (1985) Japan's Steel Industry, Tekkou Shimbun Sha, Ltd. Tokyo

Kemp M.C. (1960) “The Mill-Bastable Infant Industry Dogma”, Journal of Political Economy LXVIII, p. 65-67 
Komiya R. (1990) The Japanese Economy: Trade, Industry and Government, University of Tokyo Press

Krenin M.E. (1991), Arguments for protection in International Economics: A Policy Approach, Second Edition, Harcourt Brace Jovanovich, Inc.

Krugman P. R. (1987) "Targeted Industrial Policies: Theory and Evidence" in The New Protectionist Threat to World Welfare, ed. by D. Salvatore, Amsterdam, NorthHolland

Krugman P.R. (1992) "Import Protection as Export Promotion: International Competition" in The Presence of Oligopoly and Economies of Scale in Imperfect Competition and International Trade, ed. by G.M. Grossman, The MIT Press Cambridge, Massachusetts

Ministry of Trade and Industry, Yearbook of Iron and Steel Statistics, Various Years

Odagiri H. and A. Goto (1996), Technology and Industrial Development in Japan, Clarendon Press- Oxford

Pomfred R. (1991) International Trade, An Introduction to Theory and Policy, Basil Bleckwell

Sakurai M. (2000) Industrial Policy of Japan, Research Center for International Finance, Mitsui Kaijyo Research Center

Sazanami Y. (1994) "Japanese Industrial Policy" in Industrial Policies in the Pacific, ed. by Sletmo G.K. and G.Boyd, Westview Press, Oxford

Vestal J.E. (1993) Planning for Change: Industrial Policy and Japanese Economic Development, 1945-1990, Oxford, Clarenton Press

Yonekura S. (1991) The Postwar Japanese Iron and Steel Industry, Continuity and Discontinuity in Changing Patterns of International Rivalry, University of Tokyo Press 